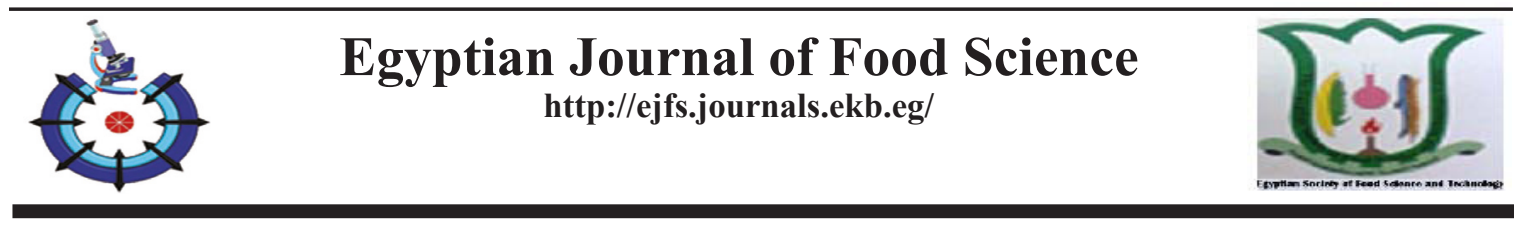

\title{
Improving The Texture Properties of Camels' Milk Rayeb
}

Marwa M. Desouky

Dairy Unit, Breeding Department, Animal Production division, Desert Research Center, Matariya 11753, Cairo, Egypt.

\begin{abstract}
CAMELS' milk produces weak texture when it is turned to fermented products. This study is planned to improve the weak texture of Rayeb camels' milk by using camel sweet curd (CSC). Sweet curd was traditionally prepared and well mixed by different ratios $(0,5,10,15$, 20 and 25\%) with fresh camel milk before Rayeb-camel-milk-processing. Physicochemical properties and microstructure examination of fresh samples were assayed. Sensory properties were evaluated for all treatments during the storage period $\left(6 \pm 0.5^{\circ} \mathrm{C}\right.$ for 15 days). The supplementation of camels' milk with CSC reduced the fermentation time, particularly with high ratios $(\geq 15 \%)$. The results show also that both the whey syneresis and $\mathrm{pH}$ values were decreased $(\mathrm{p} \leq 0.05)$ meanwhile; dynamic viscosity was increased in all treatments till the end of the storage period. The microstructure examination showed different desirable uniform protein matrix aggregates among treatments. In conclusion; camels' Rayeb milk could be successfully prepared by using camel sweet curd, with good quality attributes and highly accepted panelists scores. It could be considered a useful tool to solve the challenges of producing fermented camels' milk product "Rayeb"
\end{abstract}

Keywords: Camels' milk Rayeb, Physicochemical properties, Microstructure, Sensory evaluation.

\section{Introduction}

In Egypt, camels are considered the most important animal for Bedouins in arid and semi-arid zones as the main source of animal food, primarily camel milk. Camels produce about 2.9 million tons of milk per year. The popularity of camels' milk dairy products has spread now not only to North Africa, the Arabian Gulf area but also to the European markets (FAO, 2017). Camel milk is endowed with unique nutritional and therapeutic properties. Its proteins represent a bioactive compound that promotes consumer health by acting as hypoglycemic, hypo-allergic, immune stimulants and anti-carcinogenic (Mudgil et al., 2018). Furthermore, camels' milk contains high protective whey proteins, a higher content of anti-microbial factors (such as lysozyme, immunoglobulin, and lactoferrin). The longer shelf life of camel milk is referred to its dynamic antimicrobial system and low molecular antibodies (Hailu et al., 2016 and Al-Shamsi et al., 2018).

Despite the uniqueness nutritional and health benefits of camels' milk, it characterized with long coagulation time, a watery consistency fragile and weak curd structure by a lactic acid fermentation process. (Desouky, 2017). The poor ability of camel milk to yield desirable and acceptable fermented dairy products is mainly due to its antimicrobial agents that interfere with the starter action. Other causes could due to the small size of fat globule and its protein nature which shows low content of K-casein with a high content of the large size casein micelles (El Hatmi et al., 2014 and Kamal et al., 2017).

In Egypt "Rayeb" is a traditional fermented dairy product that has been recognized and greatly valued by consumers for centuries. It is produced by spontaneous fermentation of milk (Abou-

*Corresponding author:desouky marwa @yahoo.com

Received:3/3/2020; accepted:16/4/2020

DOI: 10.21608/EJFS.2020.25124.1043

C2020 National Information and Documentation Centre (NIDOC) 
Dobara et al., 2017). During the manufacture of fermented milk products, a necessary step is the initiation of gel configuration, that is, deterioration of the colloidal organization of casein micelles by acidification through lactic acid bacteria. Once destabilized, the casein micelles start collective and lastly form a three-dimensional arrangement entrapping the serum phase (Lee and Lucey, 2010). One of the major aims of fermented milk producers is to prepare a formula with the greatest protein, adequate dry matter, and maximum stability. Dairy proteins could offer suitable functional and technological properties (bland flavor, improve-texture properties) in dairy processing. Nowadays, dairy powders, milk protein concentrate could be integrated into the milk bases to improve the texture properties. (Desouky et al., 2019).

The configuration of the gel produced from fermented camels' milk is very poor and fragile. Recently, fermented camels milk is manufacturing using different techniques to provide the product with desirable and acceptable properties. Furthermore, the texture and the ability to retain water of fermented products is a significant quality attribute, affects its acceptability. Various attempts were conducted to resolve this problem by using skimmed milk powder (Salih and Hamid, 2013), enzymes (Hashim et al., 2009), stabilizers (Al-Zoreky and Al-Otaibi, 2015), hydrocolloids (Desouky, 2017) and cereals (Desouky and Awad, 2019). Yet, camels' milk rennet curd not used before in fermented milk products as "Rayeb". Taking all the above mentioned in concern; this study aimed to manifest the effect of adding different ratios of camels' sweet curd (CSC) as a technological step for texture improvement or modification of camels' milk Rayeb. The physicochemical properties and the microstructural examination of fresh samples were assayed while the sensory quality attributes were evaluated during the storage period.

\section{Materials and Methods}

\section{Materials}

Raw camels' milk was collected from camels' herd belongs to Desert Research Center at North Western Coastal area, Matrouh Governorate, Egypt. Milk was immediately maintained and stored under refrigerated conditions until used. Bulk camels' milk samples contained 12.55 $\pm 0.62 \%$ total solids, $3.83 \pm 0.29 \%$ fat, 3.56 $\pm 0.18 \%$ total protein, $4.32 \pm 0.12 \%$ carbohydrates (by the difference), $0.84 \pm 0.08 \%$ ash and $\mathrm{pH}$ value of $6.6 \pm 0.24$

Camel specific liquid Chymosine (CHYMAX $\mathrm{M}^{\mathrm{TM}}, 1000 \mathrm{IMCU} \mathrm{mL}^{-1}$ ) and commercial freeze- dried DVS mixed-bacterial-starters namely : YoFast1 (containing of Lactobacillus delbrueckii ssp. bulgaricus and Streptococcus thermophilus as Rayeb starter was purchased from Chr. Hansen Laboratory (Copenhagen, Denmark).

Freeze-dried bacterial starters were activated separately in autoclaved $\left(121^{\circ} \mathrm{C} / 10 \mathrm{~min}\right)$ buffaloes' skim milk ( $0.1 \%$ fat and $9.5 \%$ SNF) using a $0.02 \%$ $(\mathrm{w} / \mathrm{v})$ inoculums. The cultures were incubated at 42C until curdling. Culture was activated $24 \mathrm{hr}$ before use.

\section{Preparing of camels' sweet curd (CSC)}

Camels' sweet curd was made by the traditional method as described by Abou-Donia (1986) with some modifications. Milk (10 kg) was pasteurized at $63^{\circ} \mathrm{C} / 30 \mathrm{~min}$ then cooled to $40^{\circ} \mathrm{C}$. Appropriate amount of rennet $(3 \mathrm{~g} / 100 \mathrm{~kg}$ milk) was added, stirred well, and milk samples were held until coagulated $(\sim 2.5-4 \mathrm{hr})$. The curd was scooped into small perforated cheese moulds at room temperature for $24 \mathrm{hr}$. and left to drain whey. The curd contained $26.56 \pm 0.24 \%$ total solids, $9.27 \pm 0.11 \%$ fat, $12.28 \pm 0.15 \%$ total protein, $3.20 \pm 0.10 \%$ carbohydrates (by the difference), $1.81 \pm 0.07 \%$ ash and had $\mathrm{pH}$ value of $6.55 \pm 0.10$.

\section{Manufacture of camels' milk Rayeb}

Camels' milk was homogenized at $55-60^{\circ} \mathrm{C}$ for $2 \mathrm{~min}$ using a high-speed mixer $(30000 \mathrm{rpm} / \mathrm{min}$ $1 X$ 520, UAC 30-R, Chicago II 6064), heated in a water bath at $85^{\circ} \mathrm{C}$ for $30 \mathrm{~min}$, and divided into six portions. The first portion was considered as a control and 5, 10, 15, 20 and $25(\mathrm{~g} / 100 \mathrm{~g})$ of CSC were added separately to the other five portions of milk and mixed well, then cooled to $42 \mathrm{C}$, inoculation with $3 \%(\mathrm{v} / \mathrm{v})$ of Yo-Fastl activated culture $\left(10^{8}-10^{9} \mathrm{cfu} / \mathrm{ml}\right)$, then incubated to $\sim 4$ h. After that immediately cooled at $6 \pm 0.5^{\circ} \mathrm{C}$ for $6 \mathrm{hr}$, all portions were manually blended and dispensed into $150 \mathrm{ml}$ plastic bottles, covered and stored at $6 \pm 0.5 \mathrm{C}$ for 15 days. Fresh Rayeb samples from different treatments were subjected to physicochemical properties, dynamic viscosity, $\mathrm{pH}$ values and organoleptic properties throughout storage period (zero, 3, 6, 9, 12 and 15 days at $6 \pm 0.5^{\circ} \mathrm{C}$.)

\section{Chemical and physicochemical determinations}

The total solids, fat, total nitrogen and ash contents; as well as $\mathrm{pH}$ values using digital $\mathrm{pH}$ meter (Inolad model 720, Germany) were determined in fresh camels' milk and Rayeb samples according to AOAC (2012). Total carbohydrates were calculated by the difference. Syneresis was measured as described by Farouq and Haque (1992) as the amount of spontaneous whey $(\mathrm{ml} / 100 \mathrm{~g})$ drained off after $2 \mathrm{hr}$ at $7^{\circ} \mathrm{C}$. 
Apparent viscosity of Rayeb samples was also measured at room temperature using a Brookfield digital viscometer (Middleboro, MA 02346, USA) using the RV spindle (No. 4) and a rotation of $100 \mathrm{rpm}$. The sample was subjected to shear rates ranging from 3-100 SG4 for an upward curve. Viscosity measurements were expressed as centipoise (cP.s) as described by Djurdjevic' et al. (2001).

\section{Microstructure examination}

The microstructure assaying of fresh camels' Rayeb treatments were achieved using transmission electron microscopy following the method of Garcia-Risco et al. (2000). Samples were viewed by SEM (JXA-840A Electron Probe Microanalyzer-JEOL, Japan) after dehydration by Critical Point Dried instrument and coating with gold using S150A Sputter Coater-Edwards, England.

\section{Sensory evaluation}

Sensory evaluation was carried out according to the sheet described by Clark et al. (2009) for flavour (1-10 points), body and texture (1-5 points) and appearance \& color (1-5 points), performed by 15 staff members of the Animal Production Division, Desert Research Center, Cairo, Egypt. All samples were evaluated when fresh and throughout storage for 15 days at $6 \pm 0.5^{\circ} \mathrm{C}$.

\section{Statistical analyses}

All experiments and analysis were done in triplicate. Statistical analyses of data were carried out using the General Linear Models procedure of the SPSS, 16.0 Syntax Reference Guide (SPSS, 2007) The results were expressed as least squares means with standard errors of the mean. Statistically different groups were determined by the LSD ( $\mathrm{p} \leq 0.05)$.

\section{Results and Discussion}

Chemical composition and physicochemical properties of camels' Rayeb milk samples fortified with different ratios of camel sweet curd (CSC)

The chemical composition of Rayeb samples were significantly $(\mathrm{p} \leq 0.05)$ influenced by the addition of CSC. The total solids, protein, fat and ash contents were high in the treatments fortified with CSC being the highest and lowest values in $\mathrm{T} 5$ and $\mathrm{T} 1$, in the same order. It could be due to the chemical composition of the sweet curd and its concentrated content of protein, fat and total solids. The high total solids in treatments enriched with CSC led to low $\mathrm{pH}$ values compared with control. However, the values of $\mathrm{pH}$ confirmed these results (Table 1). The obtained data were confirmed also by Estevez et al. (2010). Furthermore, the addition of CSC significantly $(\mathrm{P} \leq 0.05)$ improved the acidity production by the starter culture used (Tamime and Robinson, 2007). Meanwhile, the control treatment was characterized by the lowest chemical composition values expect the $\mathrm{pH}$. It could be due to the complex matrix which formed between casein and whey protein during heat treatment, which influences hydration of casein molecular and whey separation resulted in soft and watery curd or low total solid content (Al Shamsi et al., 2018).

TABLE 1. Chemical composition and $\mathrm{pH}$ values (Mean \pm Standard deviation) of fresh camels' Rayeb milk samples fortified with different ratios of camel sweet curd (CSC).

\begin{tabular}{|c|c|c|c|c|c|c|}
\hline \multirow{2}{*}{ Properties } & \multicolumn{6}{|c|}{ Treatments* } \\
\hline & Control & T1 & $\mathbf{T} 2$ & T3 & T4 & T5 \\
\hline Total solids \% & $13.33^{\mathrm{f}}$ & $14.53^{\mathrm{e}}$ & $15.63^{\mathrm{d}}$ & $16.74^{\mathrm{c}}$ & $17.69^{\mathrm{b}}$ & $18.61^{\mathrm{a}}$ \\
\hline Fat $\%$ & $3.97^{\mathrm{d}}$ & $4.28^{\mathrm{cd}}$ & $4.69^{\mathrm{bc}}$ & $5.08^{\mathrm{b}}$ & $5.41^{\mathrm{ab}}$ & $5.76^{\mathrm{a}}$ \\
\hline Total protein $\%$ & $3.79^{\mathrm{e}}$ & $4.43 \mathrm{~d}^{\mathrm{e}}$ & $5.03^{\mathrm{cd}}$ & $5.63^{b c}$ & $6.06^{\mathrm{ab}}$ & $6.55^{\mathrm{a}}$ \\
\hline Total carbohydrate $\% * *$ & $4.67^{c}$ & $4.88 b^{c}$ & $4.92^{\mathrm{abc}}$ & $4.99^{\mathrm{ab}}$ & $5.14^{\mathrm{a}}$ & $5.19^{\mathrm{a}}$ \\
\hline Ash \% & $0.90^{\mathrm{b}}$ & $0.94^{\mathrm{b}}$ & $0.99^{\mathrm{ab}}$ & $1.04^{\mathrm{a}}$ & $1.08^{\mathrm{a}}$ & $1.11^{\mathrm{a}}$ \\
\hline $\mathrm{pH}$ value & $5.36^{\mathrm{a}}$ & $5.34^{\mathrm{a}}$ & $5.32^{\mathrm{a}}$ & $5.30^{\mathrm{ab}}$ & $5.27^{\mathrm{b}}$ & $5.24^{\mathrm{b}}$ \\
\hline
\end{tabular}

* Control: Camels Rayeb milk made without camel sweet curd (CSC).

T1: Control $+5 \%$ CSC.

T2: Control $+10 \%$ CSC.

T3: Control $+15 \%$ CSC.

T4: Control $+20 \%$ CSC.

T5: Control $+25 \%$ CSC.

**calculated by the difference.

Small letters ( $a, b, c, \ldots)$ means with the different small superscript letters within the same column are significantly (P $\square 0.05)$ different between camels' rayeb milk fortified with different ratios of camel milk sweet curd (CSC) 
The $\mathrm{pH}$ values and the whey off $(\mathrm{ml} / 100 \mathrm{~g})$ of camels' Rayeb samples were significantly ( $\mathrm{s}$ 0.05 ) affected by both of the CSC fortification levels and storage period as shown in Table 2. There was a slight and gradual decrease $(\mathrm{p} \leq 0.05)$ in the $\mathrm{pH}$ values of all fortified Rayeb treatments as compared with the control being the lowest values at $\mathrm{T} 5$ treatments either when fresh (5.24) or and the end of storage (5.01). This could be attributed to the high activity of starter culture thus lowering the $\mathrm{pH}$ (Tamime and Robinson, 2007). Consequently, the high $\mathrm{pH}$ values of the control may be due to the presence of denatured whey proteins on the surface of casein micelles, being accountable for increasing the $\mathrm{pH}$ values (Lucey et al., 1998). As shown in Table 2, in the early days of cooled storage; the $\mathrm{pH}$ decreasing was more rapidly in contrast with last days of the storage period, which could be associated higher activity of free microorganisms due to rich medium at first days of storage as compared with the ending storage period. Furthermore, as CPC is considered a protein enriched fortification material for the bacterial starter culture, induced the $\mathrm{pH}$ reduction in treated samples as compared with the control. (Hai-Yan et al., 2016 and Delikanli and Ozcan, 2016). Also, the low $\mathrm{pH}$ values of the fortified CSC compared to the control treatment may be due to an increase of total solid content, being responsible for decreasing the $\mathrm{pH}$ values (Abd-El-Salam and El-Shibiny, 2015). Moreover, significant $(\mathrm{p} \leq 0.05)$ and a gradual reduction in $\mathrm{pH}$ values were detected in all treatments with expanding the storage period, due to the limited growth and acidity of different bacterial starter cultures used.

In addition, the whey separation was decreased $(p \leq 0.05)$ in all treated treatments and the control as storage time progressed till the $15^{\text {th }}$ day being the lowest values with T5 (25\% CSC) treatment till the end of storage. It is possibly due to, the whey separation in acid milk curd and the rearrangements of particles building up the casein network.

TABLE 2. Changes in $\mathrm{pH}$ values and spontaneous whey separation $(\mathrm{ml} / 100 \mathrm{~g})$ of camels' Rayeb milk samples fortified with different ratios of camel sweet curd (CSC) during storage period ( $6 \pm 0.5^{\circ} \mathrm{C} / 15$ days).

\begin{tabular}{|c|c|c|c|c|c|c|}
\hline \multirow{2}{*}{ Storage period (days) } & \multicolumn{6}{|c|}{ Treatments * } \\
\hline & Control & T1 & $\mathbf{T 2}$ & T3 & T4 & T5 \\
\hline \multicolumn{7}{|c|}{ pH values } \\
\hline Fresh & $5.36^{\mathrm{aA}}$ & $5.34^{\mathrm{aA}}$ & $5.32^{\mathrm{abA}}$ & $5.30^{\mathrm{bA}}$ & $5.27^{\mathrm{bcA}}$ & $5.24^{\mathrm{cA}}$ \\
\hline 3 & $5.32^{\mathrm{aAB}}$ & $5.29^{\mathrm{aAB}}$ & $5.27^{\mathrm{abAB}}$ & $5.25^{\mathrm{bAB}}$ & $5.22^{\mathrm{bcAB}}$ & $5.18^{\mathrm{cAB}}$ \\
\hline 6 & $5.28^{\mathrm{aB}}$ & $5.25^{\mathrm{aBC}}$ & $5.23^{\mathrm{abBC}}$ & $5.21^{\mathrm{bcBC}}$ & $5.16^{\mathrm{cdBC}}$ & $5.12^{\mathrm{dBC}}$ \\
\hline 9 & $5.24^{\mathrm{aBC}}$ & $5.21^{\mathrm{aCD}}$ & $5.19^{\mathrm{abCD}}$ & $5.17^{\mathrm{bcCD}}$ & $5.12^{\mathrm{cdCD}}$ & $5.07^{\mathrm{dCD}}$ \\
\hline 12 & $5.20^{\mathrm{ac}}$ & $5.17^{\mathrm{aD}}$ & $5.15^{\mathrm{abD}}$ & $5.13^{\mathrm{bcDE}}$ & $5.08^{\mathrm{cdD}}$ & $5.03^{\mathrm{dD}}$ \\
\hline 15 & $5.17^{\mathrm{aC}}$ & $5.14^{\mathrm{aD}}$ & $5.12^{\mathrm{abD}}$ & $5.10^{\mathrm{bE}}$ & $5.06^{\mathrm{bcD}}$ & $5.01^{\mathrm{cD}}$ \\
\hline \multicolumn{7}{|c|}{ whey separation $(\mathrm{ml} / \mathbf{1 0 0 g})$} \\
\hline Fresh & $5.27^{\mathrm{aA}}$ & $5.09^{\mathrm{bA}}$ & $4.89^{\mathrm{cA}}$ & $4.73^{\mathrm{dA}}$ & $4.49^{\mathrm{eA}}$ & $4.22^{\mathrm{fA}}$ \\
\hline 3 & $4.81^{\mathrm{aB}}$ & $4.62^{\mathrm{bB}}$ & $4.37^{\mathrm{cB}}$ & $4.19^{\mathrm{dB}}$ & $3.98^{\mathrm{eA}}$ & $3.74^{\mathrm{fB}}$ \\
\hline 6 & $4.48^{\mathrm{aC}}$ & $4.32^{\mathrm{bC}}$ & $4.12^{\mathrm{cC}}$ & $3.95^{\mathrm{dC}}$ & $3.75^{\mathrm{eB}}$ & $3.55^{\mathrm{fC}}$ \\
\hline 9 & $4.39^{\mathrm{aC}}$ & $4.23^{\mathrm{bC}}$ & $4.08^{\mathrm{cCD}}$ & $3.83^{\mathrm{dCD}}$ & $3.64^{\mathrm{eBC}}$ & $3.44^{\mathrm{fCD}}$ \\
\hline 12 & $4.28^{\mathrm{aD}}$ & $4.08^{\mathrm{bD}}$ & $3.92^{\mathrm{cDE}}$ & $3.72^{\mathrm{dDE}}$ & $3.55^{\mathrm{eCD}}$ & $3.35^{\mathrm{fD}}$ \\
\hline 15 & $4.14^{\mathrm{aF}}$ & $4.06^{\mathrm{bF}}$ & $3.83^{\mathrm{cE}}$ & $3.64^{\mathrm{dE}}$ & $3.42^{\mathrm{eD}}$ & $3.21^{\mathrm{fE}}$ \\
\hline
\end{tabular}

* See footnote Table1

Small letters $(\mathrm{a}, \mathrm{b}, \mathrm{c}, \ldots)$ means with the different small superscript letters within the same column are significantly (P $\square 0.05)$ different between camels' rayeb milk fortified with different ratios of camel milk sweet curd (CSC)

Capital letters (A, B, C...) means with the different capital superscript letters within the same raw indicate significant $(P \square 0.05)$ differences between storage period (days).

Egypt. J. Food. 48, No. 1 (2020) 
Also, Herrero and Requena (2006) reported that the increase in viscosity attributed to changes in protein conformations and the changes in $\mathrm{pH}$ are responsible to decrease the whey off. Meanwhile, in the control treatment, the complex is formed among casein and whey protein during heat treatment, which influences the whey separation. Also, it could be attributed to the differences in the developed acidity leading to whey separation (lowest water holding) and weak gel formation.

Changes in titratable acidity of camels' Rayeb milk samples fortified with different ratios of camel sweet curd (CSC) during fermentation

The effect of supplementing camels' milk with different levels (ranged from 5 to $25 \%$ of camel sweet curd (CSC) on the fermentation time and the titratable acidity (lactic acid/100 ml) is illustrated in Fig. 1. The results show that the fermentation time for all treatments was influenced by the CSC added. Camels' milk samples supplemented with CSC exhibited a much higher increase in the acidity as compared to un-supplemented samples during the time of fermentation. Furthermore, by elevating the level of CSC used, the fermentation time was reduced (300 min vs $240 \mathrm{~min}$ for control and T5 treatment, respectively). Moreover, the enrichment of camels' milk with CSC might be promoting the starter culture activity due to the sufficient concentration of nutrients required for the starter culture and increased acid development which is led to decreased fermentation time. These results are inconsistent with the findings of Lee and Lucey (2010) who observed that supplementing fermented milk with milk proteins leads to an increase in the solid content, thereby creating an increase in starter cultures activity and increased acid development. Also, milk supplemented with CSC had a higher speed of acid production during fermentation and a higher decline in $\mathrm{pH}$ value (Table 2) than the control treatment. This result was observed with a high level of supplementation (T5). The rapid increase in the titratable acidity, as well as the decrease in the $\mathrm{pH}$ values in supplemented samples, could be related to all of CSC nutrients that may have a stimulating effect on the activity of lactic acid bacteria (Delikanli and Ozcan, 2016).

Apparent viscosity values of camels' Rayeb milk samples fortified with different ratios of camel sweet curd (CSC)

Data in Figure 2 (A and B) for the apparent viscosity (cP.s) of camels' milk Rayeb fortified with different ratios (ranged from 5 to $25 \%$ ) of camel sweet curd (CSC) assisted significant
$(\mathrm{P} \leq 0.05)$ increases in the viscosity values with increasing the supplementation level of CSC and extending the storage period. All camels' Rayeb samples kept the same shape of the flow curve during the storage period (results are not shown). Therefore, the changes in the viscosity values were taken at a fresh (A) and end (B) of storage to access the effect storage on the viscosity of the prepared product. The viscosity values noticeably decreased as the shear rate increased in all treatments until the end of the storage period. All treatments showed a pseudoplastic shear thinning behavior throughout the storage period and behaved as a shear-thinning non- Newtonian fluid. The same results confirmed by Jumah et al. (2001). Rapid reduction at lower shear rates, followed by the downy curve at higher shear rates, were observed in all treatments. It could be due to the deformation and reduction in aggregated particles (Lee and Choo, 2015). Also, the apparent viscosity values greatly influenced as the protein and TS ratios in the milk base increase (as presented in Table 1). Among different treatments, T4 (25\% CSC) characterized with the maximum viscosity values through the investigated time of shearing and exhibited the highest increasing shifting of the flow curve, as compared with the other treatments (Fig. 2, A and B) either fresh or at the end of storage period. Contrary, the lowest apparent viscosity was recorded for the control which may be due to the weak curd formed and increased whey separation (Table 3). Water in milk curd is physically fascinated inside the gel matrix, a sense that the tendency for whey separation is principally linked to dynamics of the casein network rather than the mobility of the water molecules, also be credited to the alteration of the gel structure by addition CSC. Same results confirmed by Lee and Lucey (2010) After combining the results of transmission electron microscopy shown in Fig. 2 , it could be concluded that the hydrophobic interactions may be responsible for increasing the viscosity by changing the conformation structure. The addition of $25 \% \mathrm{CSC}$ increased the viscosity pronouncedly and extensively. Furthermore, the viscosity values of all treatments increased $(p \leq 0.05)$ until the end of the storage period being the highest values with T4 treatments. It could be correlated to a well-built protein network and lowest whey separation. The same trend was founded in the stirred yoghurt by Desouky (2017) who reported that, the longer the storage time was, the higher the viscosity was created. 
TABLE 3. Sensory evaluation scores of camels' Rayeb milk samples fortified with different ratios of camel sweet curd (CSC) during storage period $\left(6 \pm 0.5^{\circ} \mathrm{C} / 15\right.$ days).

\begin{tabular}{|c|c|c|c|c|c|c|c|}
\hline \multirow{2}{*}{$\begin{array}{c}\text { Organoleptic } \\
\text { properties (points) }\end{array}$} & \multirow{2}{*}{$\begin{array}{c}\text { Storage } \\
\text { period } \\
\text { (days) }\end{array}$} & \multicolumn{6}{|c|}{ Treatments * } \\
\hline & & Control & T1 & $\mathbf{T} 2$ & T3 & T4 & T5 \\
\hline \multirow{3}{*}{ Flavour } & Fresh & $18.50^{\mathrm{aA}}$ & $18.50^{\mathrm{aA}}$ & $18.50^{\mathrm{aA}}$ & $18.50^{\mathrm{aA}}$ & $18.50^{\mathrm{aA}}$ & $18.50^{\mathrm{aA}}$ \\
\hline & 3 & $18.50^{\mathrm{aA}}$ & $18.50^{\mathrm{aA}}$ & $18.50^{\mathrm{aA}}$ & $18.50^{\mathrm{aA}}$ & $18.50^{\mathrm{aA}}$ & $18.50^{\mathrm{aA}}$ \\
\hline & 6 & $18.00^{\mathrm{bB}}$ & $18.50^{\mathrm{aA}}$ & $18.50^{\mathrm{aA}}$ & $18.50^{\mathrm{aA}}$ & $18.00^{\mathrm{bB}}$ & $18.00^{\mathrm{bB}}$ \\
\hline \multirow[t]{3}{*}{$(1-20)$} & 9 & $17.50^{\mathrm{cC}}$ & $18.00^{\mathrm{bB}}$ & $18.00^{\mathrm{bB}}$ & $18.50^{\mathrm{aA}}$ & $17.70^{\mathrm{cBC}}$ & $18.50^{\mathrm{aA}}$ \\
\hline & 12 & $17.00^{\mathrm{dD}}$ & $17.50^{\mathrm{cC}}$ & $18.00^{\mathrm{bB}}$ & $18.50^{\mathrm{aA}}$ & $17.70^{\mathrm{cBC}}$ & $18.00^{\mathrm{bB}}$ \\
\hline & 15 & $16.50^{\mathrm{dE}}$ & $17.00^{\mathrm{cD}}$ & $17.70^{\mathrm{bC}}$ & $18.00^{\mathrm{aB}}$ & $17.50^{\mathrm{bC}}$ & $17.50^{\mathrm{bC}}$ \\
\hline \multirow[b]{3}{*}{ Body \& Texture } & Fresh & $8.00^{\mathrm{dA}}$ & $8.50^{\mathrm{cA}}$ & $9.50^{\mathrm{aA}}$ & $9.80^{\mathrm{aA}}$ & $9.00^{\mathrm{bA}}$ & $7.50^{\mathrm{eA}}$ \\
\hline & 3 & $8.00^{\mathrm{cA}}$ & $8.50^{\mathrm{bA}}$ & $9.50^{\mathrm{aA}}$ & $9.80^{\mathrm{aA}}$ & $8.90^{\mathrm{bAB}}$ & $7.20^{\mathrm{d} A \mathrm{~B}}$ \\
\hline & 6 & $7.50^{\mathrm{eB}}$ & $8.20^{\mathrm{dAB}}$ & $9.20^{\mathrm{bAB}}$ & $9.60^{\mathrm{aAB}}$ & $8.60^{\mathrm{cBC}}$ & $7.00^{\mathrm{fB}}$ \\
\hline \multirow{4}{*}{$(1-10)$} & 9 & $7.00^{\mathrm{dC}}$ & $8.00^{\mathrm{cBC}}$ & $9.00^{\mathrm{aBC}}$ & $9.30^{\mathrm{aBC}}$ & $8.50^{\mathrm{bCD}}$ & $6.50^{\mathrm{eC}}$ \\
\hline & 12 & $6.80^{\mathrm{dCD}}$ & $7.80^{\mathrm{cCD}}$ & $8.60^{\mathrm{abCD}}$ & $9.00^{\mathrm{aC}}$ & $8.20^{\mathrm{bDE}}$ & $6.00^{\mathrm{eD}}$ \\
\hline & 15 & $6.50^{\mathrm{eD}}$ & $7.50^{\mathrm{dD}}$ & $8.30^{\mathrm{bD}}$ & $9.00^{\mathrm{aC}}$ & $8.00^{\mathrm{cE}}$ & $6.00^{\mathrm{fD}}$ \\
\hline & Fresh & $8.00^{\mathrm{dA}}$ & $8.50^{\mathrm{cA}}$ & $9.50^{\mathrm{aA}}$ & $9.80^{\mathrm{aA}}$ & $9.00^{\mathrm{bA}}$ & $7.50^{\mathrm{eA}}$ \\
\hline \multirow{2}{*}{$\begin{array}{l}\text { Appearance \& } \\
\text { colour }\end{array}$} & 3 & $8.00^{\mathrm{cA}}$ & $8.50^{\mathrm{bA}}$ & $9.50^{\mathrm{aA}}$ & $9.80^{\mathrm{aA}}$ & $8.90^{\mathrm{bAB}}$ & $7.20^{\mathrm{dAB}}$ \\
\hline & 6 & $7.50^{\mathrm{dB}}$ & $8.20^{\mathrm{cAB}}$ & $9.20^{\mathrm{bAB}}$ & $9.80^{\mathrm{aA}}$ & $8.60^{\mathrm{cAB}}$ & $7.00^{\mathrm{eB}}$ \\
\hline \multirow{3}{*}{$(1-10)$} & 9 & $7.50^{\mathrm{eB}}$ & $8.00^{\mathrm{dB}}$ & $9.00^{\mathrm{bB}}$ & $9.50^{\mathrm{aA}}$ & $8.50^{\mathrm{cB}}$ & $7.00^{\mathrm{fB}}$ \\
\hline & 12 & $7.50^{\mathrm{eB}}$ & $8.00^{\mathrm{dB}}$ & $9.00^{\mathrm{bB}}$ & $9.50^{\mathrm{aA}}$ & $8.50^{\mathrm{cB}}$ & $7.00^{\mathrm{fB}}$ \\
\hline & 15 & $7.50^{\mathrm{eB}}$ & $8.00^{\mathrm{dB}}$ & $9.00^{\mathrm{bB}}$ & $9.50^{\mathrm{aA}}$ & $8.50^{\mathrm{cB}}$ & $7.00^{\mathrm{fB}}$ \\
\hline
\end{tabular}

*See footnote Table 2 Control: Camels' Rayeb milk made without camel sweet curd (CSC).

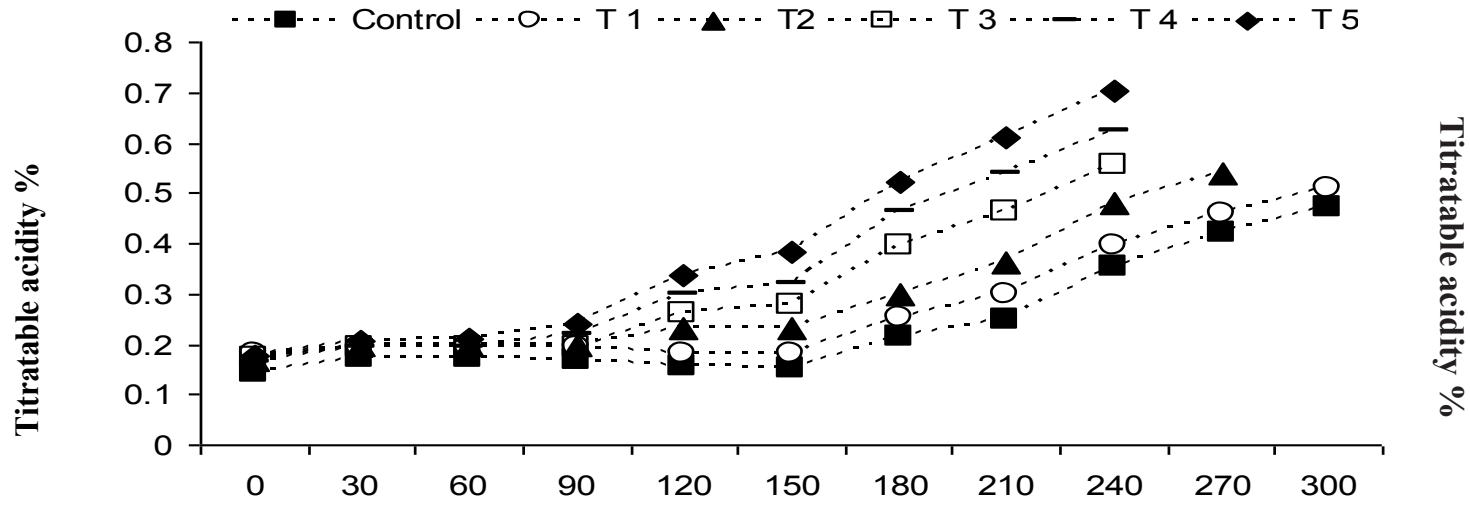

Fermentation time (min)

Fig.1. Changes in titratable acidity (Mean \pm standard deviation) of camels' Rayeb milk samples fortified with different ratios of camel sweet curd (CSC) ranged from 5 to $25 \%$ during fermentation.

T1: Control + $5 \%$ CSC.
T2: Control + $10 \%$ CSC.
T3: Control + $15 \%$ CSC.
T4: Control $+20 \%$ CSC.
T5: Control $+25 \%$ CSC. 
(A)

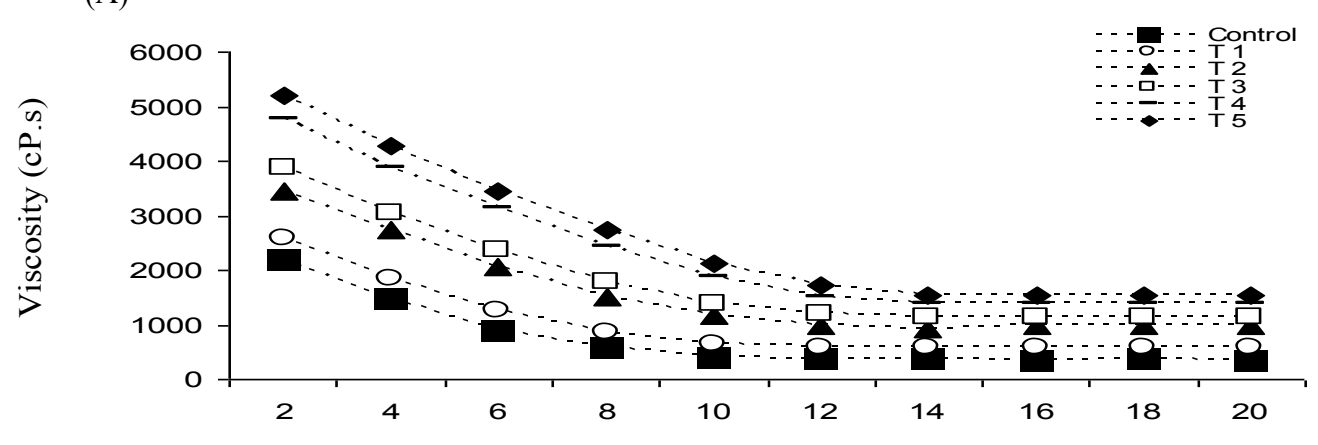

(B)

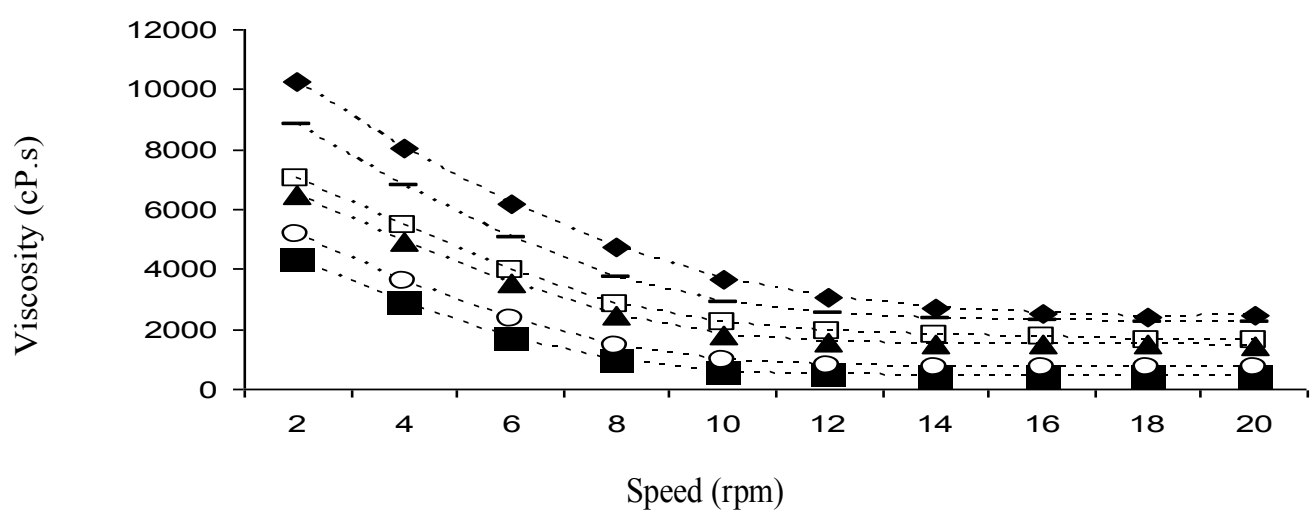

Fig. 2. Viscosity of camels' rayeb samples fortified with different ratios of camel sweet curd (CSC) when fresh (A) and after $15(B)$ days of storage period at $6 \pm 0.5^{\circ} \mathrm{C}$, respectively.

See footnote Fig. 1

Microstructure of camels' Rayeb milk samples fortified with different ratios of camel sweet curd (CSC)

Figure 3 shows the microstructures of fresh camels' Rayeb treatments fortified with different ratios (ranged from 5 to $25 \%$ ) of camel sweet curd (CSC) using transmission electron microscopy. The microstructures of different treatments were similar exhibiting casein micelle chains and clusters $(\mathrm{P})$ separated by voids volumes $(\mathrm{V})$. The sizes of casein clusters and protein aggregates were not the same between the different treatments. Rayeb prepared using different ratios of CSC showed homogenous and comparatively steady network structure with quite little and consistently distributed pores, with increasing the fortification level the prepared Rayeb showed the small number of large voids. While, the control treatment showed a more open, unfastened and fewer dense protein matrix and characterized by small casein micelles aggregates chains, no substantial huge ones were detected. Also, the voids represent areas, an excess which leads to an open or loose texture (Wang et al., 2012), leading to a weaker gel (Torres et al., 2018) and it is confirmed with the observed lower viscosity (as shown in Fig. 2) in the control. According to the previous study, hydrophobic associations play a role in molecular structuring (Eissa, 2013). Since the $\mathrm{pH}$ is decreased, the electrostatic repulsions among the casein molecules are lowered. Hydrophobic interactions will increase leading to the configuration of a three-dimensional protein net comprised of casein strands (Phadungath, 2005) as observed in the treated treatments casein micelles aggregates were linked continuously and strongly as the effect of the CSC. This may explain the increase in viscosity with increasing the concentration used. A compact network was observed at the higher concentrations (T3 and T4), the pore size was much smaller and showed comparatively steady network configuration with rather small and consistently dispersed pores and 


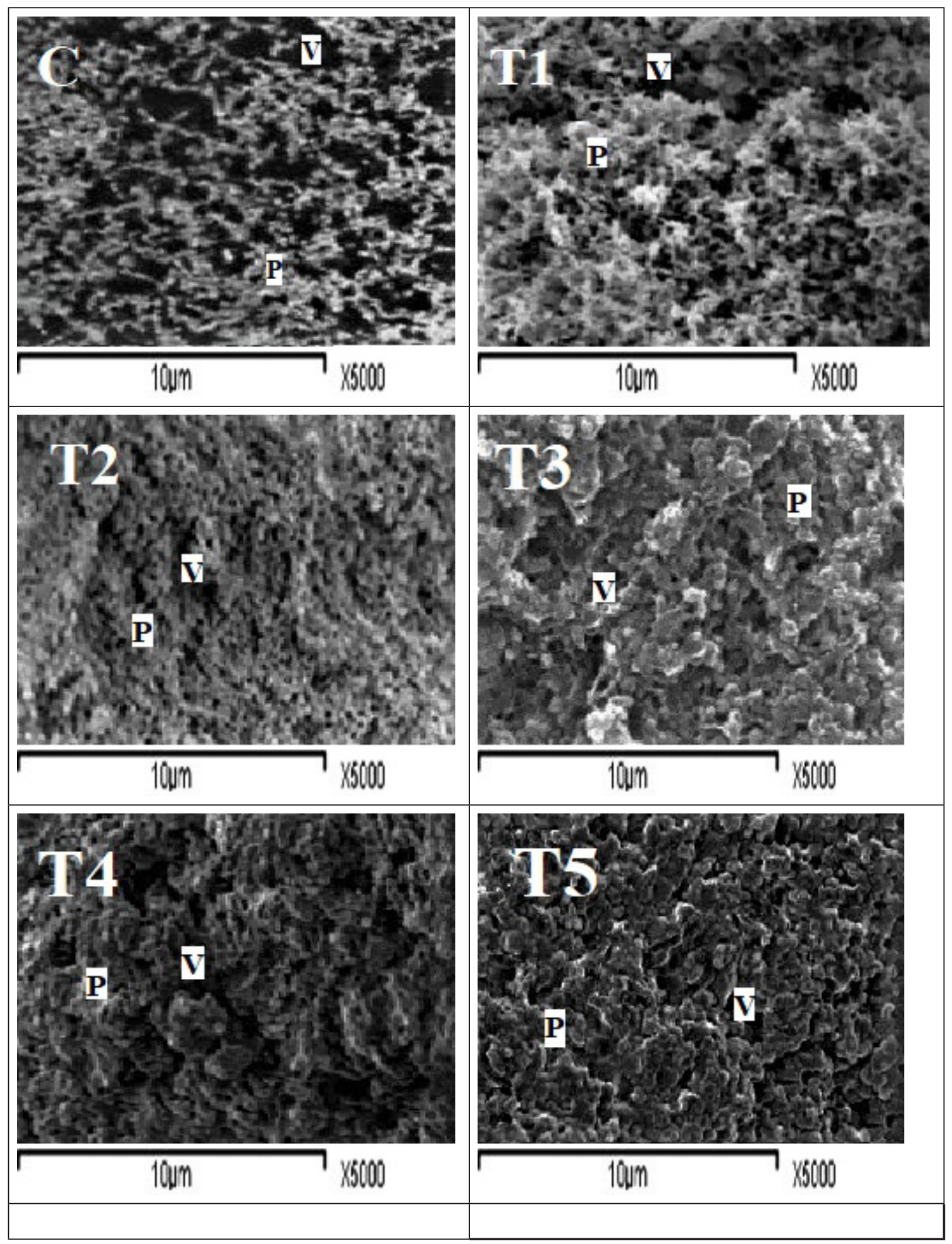

Fig. 3. Scanning electron microscopy (x5000) images of fresh camels' rayeb milk samples fortified with different ratios of camel sweet curd (CSC) (ranged from 5 to 25\%) See footnote Fig. 1. 
showed a small number of large voids because it is high viscosity than that of low concentration (T1). It could be due to, if the casein micelles bond too powerfully, water holding capacity will reduce. Also, fortification with different types of milk protein ingredients resulted in higher viscosity, stronger networks and a smaller syneresis amount than non-fortified treatments (Karam et al., 2013).

Sensory properties of camels' Rayeb milk samples fortified with different ratios of camel sweet curd (CSC) during cold storage

The sensory evaluations of fresh and stored camels' Rayeb samples fortified with different ratios $(5-25 \%)$ of camel sweet curd (CSC) are presented in Table 3. Overall, the study showed the good sensory quality of the Rayeb. All treatments were acceptable with significant differences $(p \leq 0.05)$ between them, where the CSC levels used and the storage time were the major factors influencing the sensory properties. All treatments had a good quality appearance, body and texture (soft, smooth and lubricity texture) and pleasing creamy flavor. No obvious change detected in color and appearance either in fresh or in stored treatments. All of the panelists acknowledged the sensory quality of the prepared camels' Rayeb fortified products, which may be due to rich and sweetness imparted by the high sweet curd added, which had a significant effect on the sensory evaluation. It could be due to that, the addition of milk protein ingredient considerably offers suitable functional properties as good water-binding capacity, gel-forming and thickening capacities which will develop higher obvious differences between treated treatments as compared to the control. The same findings confirmed by Crowley et al. (2015). Also, all treatments were characterized by white color and acceptable until the end of a cold storage period. The whey separation appeared to be decreased during storage in all treatments including control. Moreover, the acceptability of all treated Rayeb treatments with CSC was rated above average. Rayeb treatments made with $5 \mathrm{~g} / 100 \mathrm{~g}$ CSC (T1) showed a slightly soft body and smooth texture as compared with all other treated treatments; meanwhile $25 \mathrm{~g} / 100 \mathrm{~g}$ CSC added gained the lowest body texture scores. Generally, it has been observed that enriching the fortification base with CSC favorites a granular texture. Among all treated treatments, T3 (fortified with 15\% CSC) gained the highest preference (rich flavor, creamier consistency body \& texture, as well as whiteness and acceptable color) followed by T2 contains $10 \% \mathrm{CSC}$ until the end of storage period.
Additionally, the total sensory quality attributes (flavor, body \& texture, and appearance) of all the Rayeb treatments decreased $(p \leq 0.05)$ with extending the storage period. These trim down started to be watched after the $6 \stackrel{\text { th }}{\text { day of }}$ storage and all treatments scored the lowest at the 15 th day of refrigeration storage period (Table 3 ). Similar findings reported Lee and Lucey (2010).

\section{Conclusion}

From the foregoing, it could be concluded that using different concentrations (5-25\%) of camel sweet curd (CSC) in the manufacture of camels' Rayeb milk as texture modifier were significantly $(p \leq 0.05)$ improved the physicochemical, microstructural characteristics and data were preferred by the sensory panelists throughout the storage period $\left(6 \pm 0.5^{\circ} \mathrm{C}\right.$ for 15 days). Among treated samples; fortifications with 10 and $15 \%$ CSC gained the highest quality attributes throughout the storage period and could be recommended as texture modifier for the processing of camels' Rayeb milk.

\section{References}

Abou-Dobara, M. I., Ismail, M. M., Abdu Mossa, M. and Refat, N. M. (2017) Effect of Using Vegetarian Milk and Adding Different Sweeteners on Probiotic Activity of Rayeb Milk. American Journal of Microbiology and Biotechnology, 4, 4452.

Abou-Donia, S.A. Egyptian Domiati soft white pickled cheese (1986) Review. New Zealand J. Dairy Sci. and Tech. 21, 167-190.

Al-Shamsi, K., Mudgil, P., Hassan, H. and Maqsood, S. (2018) Camel milk protein hydrolysates with improved techno-functional properties and enhanced antioxidant potential in vitro and in food model systems. Journal of Dairy Science, 101, 4760.

Al-Zoreky, N.S. and Al-Otaibi, M.M. (2015). Suitability of camel milk for making yoghurt. Food Science and Biotechnology, 24, 601-606.

AOAC (2012) Official Methods of Analysis. Association of Official Analytical Chemists, Gaithersburg, MD, USA.

Clark, S., Costello, M., Drake, M. and Bodyfelt, F. (2009) The sensory Evaluation of Dairy Products. ( $\left.2^{\text {nd }} E d\right)$, pp.191-223. Springer Science Business Media, LLC, New York, USA,

Egypt. J. Food. 48, No.1 (2020) 
Crowley, S., Desautel, B., Gazi, I., Kelly, A., Huppertz, J. and O'Mahoney, J. (2015) Rehydration characteristics of milk protein concentrate powder. Journal of Food Engineering 149 105-113.

Delikanli, B. and Ozcan, T. (2016) Improving the textural properties of yoghurt fortified with milk proteins. Journal of Food processing and Peservation, 1-8.

Desouky, M. M. (2017) Preparation and properties of camels' milk yoghurt drinks. Egyptian Journal of Dairy Science, 45 181-196.

Desouky, M.M. and Awad, R. A. (2019) Characteristics of functional synbiotic camels'fermented milk (like- yoghurt) products. Scientific Research and Reviews, 12, 101-112.

Desouky, M. M., Salama, H.H. and El-Sayed, S.M. (2019) The effects of camel milk powder on the stability and quality properties of processed cheese sauce. Acta Scientiarum Polonorum Technologia Alimentaria, 18, 1-11.

Djurdjevic', J.D., Macej, O. and Jovanovic, S. (2001). The influence of dry matter and heat treatment on the viscosity of set-style yoghurt produced from reconstituted skim milk powder. Journal of Agricultural Science, 46, 123 -135.

Eissa , A. S. (2013) Newtonian viscosity behavior of dilute solutions of polymerized whey proteins. Would viscosity measurements reveal more detailed molecular properties? Food Hydrocolloid, 30, 200-205.

El Hatmi, H., Jrad, Z., Khorchani, T., Dary, A. and Girardet, J. M. (2014) Fast protein liquid chromatography of camel alpha-lactalbumin fraction with radical scavenging activity. Emirate Journal of Food and Agriculture, 26, 309-316.

Abd-El-Salam, M. H. and El-Shibiny, S. (2015). Preparation and properties of milk proteins-based encapsulated probiotics: a review. Dairy Science and Technology, 95, 393-412.

Estevez, A.M., Mejia, J., Figuerola, F. and Escobar, B. (2010) Effect of solid content and sugar combinations on the quality of soymilk-based yoghurt. Journal of Food Process Preservation, 34, 87-97.

FAO (2017) Food and agriculture organization of the United Nations.

Farouq, K. and Haque, Z. U. (1992) Effect of sugar esters on the textural properties of the nonfat low calorie yoghurt. Journal of Dairy Science, 75, 2676-2680.

Garcia-Risco, M. R., Olano, A., Ramos, M., LopezFandino, H. and Micellar, R.(2000) Changes induced by high pressure. Influence in the proteolytic activity and organoleptic properties of milk. Journal of Dairy Science, 83, 2184-2189.

Hailu, Y., Hansen, E. B., Seifu, E., Eshetu, M., Ipsen, R. and Kappeler, S. (2016) Functional and technological properties of camel milk proteins: a review. Journal of Dairy Research, 83, 422-429.

Hai-Yan, Yu., Wang, Li., Kathryn, L. and Carthy, Mc. (2016). Characterization of yoghurts made with milk solids nonfat by rheological behavior and nuclear magnetic resonance spectroscopy. Journal of Food and Drug Analysis; 24, 804 - 812.

Hashim, B., Khalil, A. H. and Habib, H. (2009) Quality and acceptability of a set-type yoghurt made from camel milk. Journal of Dairy Science; 92, 857-862.

Herrero, A.N. and Requena, T. (2006) The effect of supplementing goats milk with whey protein concentrate on textural properties of set-type yoghurt. International Journal of Food Science and Technology; 41, 87-92.

Jumah, R. Y., Skaker, R .R. and Abu-Jdayil, B. (2001) Effect of milk source on the rheological properties of yoghurt during the gelation process. International Journal of Dairy Technology, 54, 89-93.

Kamal, M., Foukani, M. and Karoui, R. (2017) Rheological and physical properties of camel and cow milk gels enriched with phosphate and calcium during acid-induced gelation. Journal Food Science and Technology, 54, 439-446.

Karam, M. C., Laire Gaiani, C., Hosri, C., Jennifer, B. and Joël , S. (2013) Effect of dairy powders fortification on yoghurt textural and sensorial properties: a review. Journal of Dairy Research, 80, 400-409.

Lee, P. E. and Choo, W. S. (2015) Characterization of flaxseed oil emulsions. Journal of Food Science and Technology, 52, 4378-4386.

Lee, W. J. and Lucey, J .A. (2010) Formation and physical properties of Yoghurt. Asian-Australasian Journal of Animal Sciences, 23, 1127-1136.

Lucey, J .A., Tamehana, M., Singh,H. and Munro, P. A. (1998). Effect of interactions between denatured whey proteins and casein micelles on the formation and rheological properties of acid skim milk gels.

Egypt. J. Food. 48, No. 1 (2020) 
Journal Dairy Research, 65, 555-567.

Mudgil, P. Kamal, H., Chee, Yuen, G. and Maqsood, S. (2018). Characterization and identification of novel antidiabetic and anti-obesity peptides from camel milk protein hydrolysates, Food Chemhimistry, 259, 46-54.

Phadungath, C. (2005). The mechanism and properties of acid-coagulated milk gels Songklanakarin Journal of Science Technology, 27, 433-448.

Salih, M. M. and Hamid, O. I. A. (2013) Effect of fortifying camel's milk with skim milk powder on the physicochemical, microbiological and sensory characteristics of set yoghurt. Advanced Journal of Food Science Technology, 5, 765-770.

SPSS (2007) Statistical Package for Social Science. SPSS Inc., 233 South Wacker Drive, 11th Floor, Chicago, IL, USA.
Tamime, A.Y. and Robinson, R. K. (2007) Traditional and recent developments in yoghurt production and related products. In Tamime and Robinson's Yoghurt Science and Technology. 3rd ed, pp 351-354. Cambridge: Woodhead Publishing Ltd. Technology 44 2134-2140

Torres, I. C., Amigo, J. M., Knudsen, J. C., Tolkach, A., Mikkelsen, B. Ø. and Ipsen, R. (2018). Rheology and microstructure of low $\square$ fat yoghurt produced with whey protein microparticles as fat replacer. International Dairy Journal, 81, 62-71.

Wang, W., Bao, Y., Hendricks, G.M. and Guo, M. (2012). Consistancy, microstructure, and probiotic survivability of goats' milk yoghurt using polymerized whey protein as a co-thickening agent. International Dairy Journal, 24, 113-9.
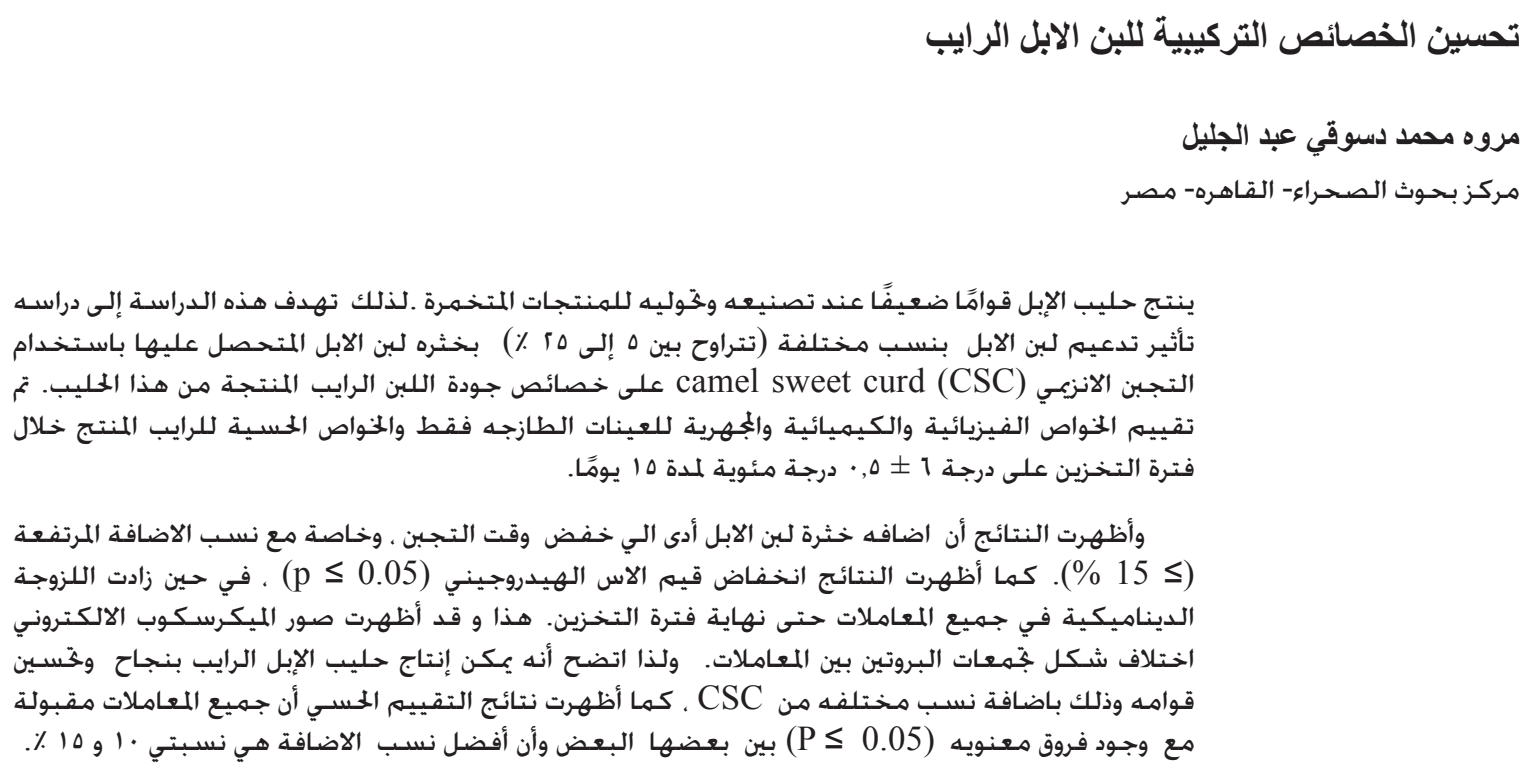